Cite this: Phys. Chem. Chem. Phys., 2013, 15, 15260

Received 28th March 2013, Accepted 18th June 2013

DOI: $10.1039 / \mathrm{c} 3 \mathrm{cp} 51326 \mathrm{~b}$

www.rsc.org/pccp

\title{
Water-gas shift on gold catalysts: catalyst systems and fundamental studies
}

\author{
Franklin (Feng) Tao*a and Zhen Ma*b
}

\begin{abstract}
Since the pioneering finding by Haruta et al. that small gold nanoparticles on reducible supports can be highly active for low-temperature $\mathrm{CO}$ oxidation, the synthesis, characterization, and application of supported gold catalysts have attracted much attention. The water-gas shift reaction (WGSR: $\mathrm{CO}+\mathrm{H}_{2} \mathrm{O}=\mathrm{CO}_{2}+\mathrm{H}_{2}$ ) is important for removing $\mathrm{CO}$ and upgrading the purity of $\mathrm{H}_{2}$ for fuel cell applications, ammonia synthesis, and selective hydrogenation processes. In recent years, much attention has been paid to exploration the possibility of using supported gold nanocatalysts for WGSR and understanding the fundamental aspects related to catalyst deactivation mechanisms, nature of active sites, and reaction mechanisms. Here we summarize recent advances in the development of supported gold catalysts for this reaction and fundamental insights that can be gained, and furnish our assessment on the status of research progress.
\end{abstract}

\section{Introduction}

$\mathrm{CO}$ and $\mathrm{H}_{2}$ mixtures with different compositions are commonly produced by steam reforming $\left(\mathrm{CH}_{4}+\mathrm{H}_{2} \mathrm{O}=\mathrm{CO}+3 \mathrm{H}_{2}\right)$, partial oxidation $\left(\mathrm{CH}_{4}+1 / 2 \mathrm{O}_{2}=\mathrm{CO}+2 \mathrm{H}_{2}\right)$, and coal gasification $\left(\mathrm{C}+\mathrm{H}_{2} \mathrm{O}=\right.$ $\mathrm{CO}+\mathrm{H}_{2}$ ) in the chemical industry. ${ }^{1-3}$ The $\mathrm{CO} / \mathrm{H}_{2}$ ratios in the $\mathrm{CO}+\mathrm{H}_{2}$ mixtures can be tuned via the water-gas shift reaction (WGSR: $\mathrm{CO}+\mathrm{H}_{2} \mathrm{O}=\mathrm{CO}_{2}+\mathrm{H}_{2}$ ) or reversed water-gas shift $\left(\mathrm{CO}_{2}+\mathrm{H}_{2}=\mathrm{CO}+\mathrm{H}_{2} \mathrm{O}\right) .{ }^{4}$ The $\mathrm{CO}+\mathrm{H}_{2}$ mixtures with suitable compositions can be used in the catalytic production of liquid fuels (via Fischer-Tropsch synthesis) or methanol (i.e., methanol synthesis). Alternatively, most of the $\mathrm{CO}$ in the $\mathrm{CO}+\mathrm{H}_{2}$ mixture can be removed via WGSR, ${ }^{5,6}$ followed by preferential oxidation of $\mathrm{CO}$ in the presence of $\mathrm{H}_{2}$, therefore enhancing the purity of $\mathrm{H}_{2}$ for fuel cell applications, ${ }^{7,8}$ ammonia synthesis, and hydrogenation of organic substrates. The upgrading of $\mathrm{H}_{2}$ is important, because the presence of a small amount of $\mathrm{CO}$ in $\mathrm{H}_{2}$ may poison the catalysts. WGSR is also involved in automobile emission control: it not only removes some $\mathrm{CO}$ in the emission, but also generates $\mathrm{H}_{2}$ that can reduce $\mathrm{NO}_{x}$.

In industries, the $\mathrm{CO}+\mathrm{H}_{2}$ mixture exiting the reactor is hot, so a high-temperature shift catalyst $\left(\mathrm{Fe}_{2} \mathrm{O}_{3}-\mathrm{Cr}_{2} \mathrm{O}_{3}\right)$ is operated at $300-450{ }^{\circ} \mathrm{C}$, and a low-temperature shift catalyst $\left(\mathrm{Cu}-\mathrm{ZnO} / \mathrm{Al}_{2} \mathrm{O}_{3}\right)$ is then used when the mixture cools to $200-300{ }^{\circ} \mathrm{C}$. These metal

\footnotetext{
${ }^{a}$ Department of Chemistry and Biochemistry, University of Notre Dame, Notre Dame, IN 46556, USA. E-mail: ftao@nd.edu

${ }^{b}$ Shanghai Key Laboratory of Atmospheric Particle Pollution and Prevention (LAP $\left.{ }^{3}\right)$, Department of Environmental Science and Engineering, Fudan University,

Shanghai 200433, P.R. China. E-mail: zhenma@fudan.edu.cn
}

oxide catalysts, although less expensive, need careful pretreatment before operation and are sensitive to the exposure to air. In addition, because the WGSR is an exothermic reaction $(\Delta H=$ $-41.4 \mathrm{~kJ} \mathrm{~mol}^{-1}$ ), its equilibrium constant decreases with the reaction temperature, ${ }^{4}$ meaning that high temperature is not favorable for achieving high CO conversion from a thermodynamic point of view. In recent years, new catalysts active for WGSR at low temperature have been in active pursuit.

Gold was initially regarded as inert in chemistry and useless in catalysis. In the 1980s, Haruta and co-workers found that gold catalysts prepared using appropriate methods on reducible supports have finely divided gold nanoparticles on supports and high activities in CO oxidation. ${ }^{9,10}$ Goodman and co-workers demonstrated that the activities of $\mathrm{Au} / \mathrm{TiO}_{2}$ model catalysts in $\mathrm{CO}$ oxidation depend critically on the size of gold nanoparticles. ${ }^{11}$ These findings have led to numerous studies on different aspects of gold catalysis, including various preparation methods and details, designs of new gold catalysts, applications of gold catalysts in environmental catalysis and organic synthesis, nature of active sites, and reaction mechanisms. ${ }^{12-40}$

Since some supported gold catalysts can catalyze CO oxidation, one logical extension is to use gold catalysts for WGSR, considering that $\mathrm{H}_{2} \mathrm{O}$ can also be an oxygen supplier. However, WGSR is more demanding than CO oxidation on gold catalysts, taking place at much higher temperatures. Although the majority of papers on gold catalysis deal with CO oxidation, still a significant number of papers are about gold-catalyzed WGSR. In the initial phase of research, the main objective was to explore gold catalyst systems for WGSR (i.e., to demonstrate that certain gold catalysts are active for this reaction) and to compare the performance of gold catalysts 
with other catalysts. Next, modified catalysts were prepared and tested, and the influences of preparation details and reaction conditions were examined. These two stages follow the traditional path of catalyst development, but question arises as to what can be learned other than the technical aspects. Then, many in-depth studies on the nature of active sites, reaction mechanisms, and deactivation mechanisms appeared, although a universal picture cannot be obtained due to different catalysts, reaction conditions, and research approaches adopted in different studies. These studies did deepen our understanding of this important reaction on gold catalysts. Here we reviewed the recent advances in fundamental studies of WGSR catalysis on supported gold catalysts.

\section{Examples on typical and usually simple catalysts}

Gold catalysts are often prepared by loading gold on solid supports such as $\mathrm{TiO}_{2}, \mathrm{ZrO}_{2}, \mathrm{CeO}_{2}, \mathrm{Fe}_{2} \mathrm{O}_{3}, \mathrm{Al}_{2} \mathrm{O}_{3}$, and $\mathrm{SiO}_{2}$, and these catalysts are usually tested in $\mathrm{CO}$ oxidation. Therefore, initial research on gold-catalyzed WGSR used some of these catalysts, especially the catalysts with reducible metal oxide supports since gold catalysts based on these supports are often more active than those based on non-reducible supports.

Andreeva et al. demonstrated the application of $\mathrm{Au} / \mathrm{Fe}_{2} \mathrm{O}_{3}$ in WGSR. ${ }^{41,42} \mathrm{Au} / \alpha-\mathrm{Fe}_{2} \mathrm{O}_{3}$ and $\mathrm{Au} / \mathrm{Al}_{2} \mathrm{O}_{3}$ were prepared via coprecipitation by mixing an aqueous solution of $\mathrm{HAuCl}_{4}, \mathrm{Fe}\left(\mathrm{NO}_{3}\right)_{3}$ or $\mathrm{Al}\left(\mathrm{NO}_{3}\right)_{3}$, and $\mathrm{Na}_{2} \mathrm{CO}_{3}$ solution at $\mathrm{pH}$ 8. $\mathrm{Au} / \alpha-\mathrm{Fe}_{2} \mathrm{O}_{3}$ showed higher catalytic activity than $\mathrm{CuO} / \mathrm{ZnO} / \mathrm{Al}_{2} \mathrm{O}_{3}$ and $\alpha-\mathrm{Fe}_{2} \mathrm{O}_{3}$, whereas $\mathrm{Au}$ / $\mathrm{Al}_{2} \mathrm{O}_{3}$ was not active. The $\mathrm{Au} / \alpha-\mathrm{Fe}_{2} \mathrm{O}_{3}$ collected after reaction testing was composed of $\mathrm{Au}, \mathrm{Fe}_{3} \mathrm{O}_{4}$, and $\mathrm{Fe}_{2} \mathrm{O}_{3}$, indicating some reduction of the support by the reducing environment. A specific interaction of gold nanoparticles and the support was responsible for the activity. ${ }^{41} \mathrm{Au} / \alpha-\mathrm{Fe}_{2} \mathrm{O}_{3}$ prepared using a modified depositionprecipitation method had higher activity. ${ }^{43}$

Additional studies have followed. For instance, Sakurai and co-workers found that $\mathrm{Au} / \mathrm{TiO}_{2}$ prepared using depositionprecipitation showed higher activity than $\mathrm{Au} / \mathrm{TiO}_{2}, \mathrm{Au} / \mathrm{Fe}_{2} \mathrm{O}_{3}$, $\mathrm{Au} / \mathrm{Al}_{2} \mathrm{O}_{3}$, and $\mathrm{Au} / \mathrm{ZnO}$ catalysts prepared using coprecipitation. ${ }^{44}$ Flytzani-Stephanopoulos and co-workers prepared $\mathrm{Au} / \mathrm{Ce}(4 \% \mathrm{La}) \mathrm{O}_{x}$ catalysts via coprecipitation or deposition-precipitation and found that the catalytic rates were comparable to that on $\mathrm{Cu} / \mathrm{CeO}_{2}$ and better than that on $\mathrm{Au} / \mathrm{TiO}_{2}$ reported previously. ${ }^{45}$ Andreeva and co-workers studied the influences of various parameters (i.e., gold loading, contact time, and the $\mathrm{H}_{2} \mathrm{O} / \mathrm{CO}$ ratio) on the catalytic activity of $\mathrm{Au} / \mathrm{CeO}_{2}$ in WGSR. ${ }^{46}$

As summarized above, $\mathrm{Au} / \mathrm{Fe}_{2} \mathrm{O}_{3}, \mathrm{Au} / \mathrm{TiO}_{2}$, and $\mathrm{Au} / \mathrm{CeO}_{2}$ were identified as active WGS catalysts in the initial phase of research. Other active catalysts include $\mathrm{Au} / \mathrm{ZrO}_{2},{ }^{47,48} \mathrm{Au} / \mathrm{Co}_{3} \mathrm{O}_{4},{ }^{48} \mathrm{Au} / \mathrm{ThO}_{2},{ }^{49}$ and $\mathrm{Au} / \mathrm{Fe}_{3} \mathrm{O}_{4} \cdot{ }^{50}$ The supports of these catalysts can usually be partially reduced, forming oxygen vacancies that may help with the catalytic reaction. On the other hand, $\mathrm{SiO}_{2}$ and $\mathrm{Al}_{2} \mathrm{O}_{3}$ that cannot be reduced are not suitable for making active WGS catalysts. ${ }^{51,52}$ Fig. 1 compares the catalytic activities of $\mathrm{Au} / \mathrm{TiO}_{2}, \mathrm{Au} / \mathrm{CeO}_{2}, \mathrm{Au} / \mathrm{Al}_{2} \mathrm{O}_{3}$, and $\mathrm{Au} / \mathrm{SiO}_{2}$ in WGSR under the same reaction condition, ${ }^{51}$ highlighting the support effect in WGSR. Carbon-supported gold

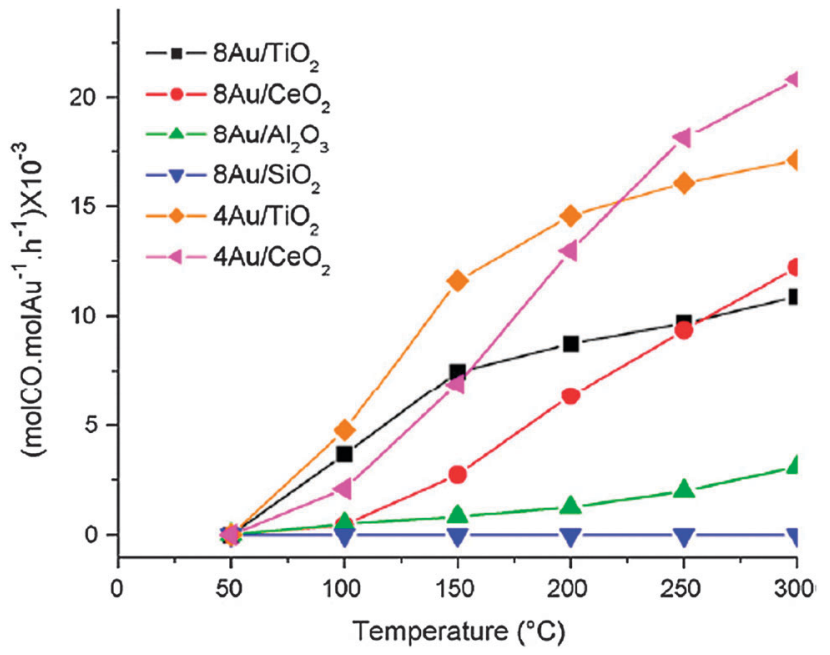

Fig. 1 Catalytic activities of $\mathrm{Au} / \mathrm{TiO}_{2}, \mathrm{Au} / \mathrm{CeO}_{2}, \mathrm{Au} / \mathrm{Al}_{2} \mathrm{O}_{3}$, and $\mathrm{Au} / \mathrm{SiO}$ in WGSR as a function of reaction temperature. ${ }^{51}$ Reproduced with permission of Elsevier from A. Sandoval, A. Gómez-Cortés, R. Zanella, G. Díaz and J. M. Saniger, J. Mol. Catal. A: Chem., 2007, 278, 200.

catalysts are often not quite active, unless the carbon support is modified by $\mathrm{TiO}_{x}$ and gold is supported afterwards to create active $\mathrm{Au}-\mathrm{TiO}_{x}$ interfaces. $^{53-55}$

The question now arises as to whether gold catalysts based on non-reducible supports are always not active for WGSR. Scurrell and co-workers loaded gold onto hydroxyapatite $\left(\mathrm{Ca}_{10}\left(\mathrm{PO}_{4}\right)_{6}(\mathrm{OH})_{2}\right)$ using deposition-precipitation and demonstrated the high activity of $\mathrm{Au} /$ hydroxyapatite in $\mathrm{WGSR}^{56}$ Interestingly, although some gold catalysts based on metal phosphate supports (most of these supports are non-reducible) were active for CO oxidation, ${ }^{5-60}$ none of them were active in WGSR. ${ }^{61}$ One possible reason is that WGSR takes place at much higher temperatures than $\mathrm{CO}$ oxidation on gold catalysts. Another reason may be that the site requirements and/or mechanisms for these two reactions are different. Additional work is still needed to better understand the difference.

\section{Development of new WGS catalysts}

Based on relatively simple catalyst systems, there are generally two lines of research. One is to study the influence of preparation procedures or details, ${ }^{62-69}$ and the other is to develop new gold catalysts, often with more complex structures, compositions, or interesting morphologies. The preparation procedures or details are known to influence the physicochemical properties and catalytic behaviors in many ways. Although the preparation and modification is a trivial task, understanding the correlations and fundamental reasons for activity difference is not trivial. For instance, Hardacre and co-workers investigated the influence of gold deposition methods, type of the gold precursor, nature of the washing solution, drying methods, as well as the $\mathrm{Ce} / \mathrm{Zr}$ ratio and sulfation of the $\mathrm{CeZrO}_{4}$ support on catalytic performance. ${ }^{70}$ It was nicely shown that the catalytic activities of $\mathrm{Au} / \mathrm{CeZrO}_{4}$ catalysts prepared differently correlated to the $\mathrm{Au}-\mathrm{CO}$ band areas detected by FT-IR (Fig. 2). ${ }^{70}$ In that work, CO was used as a 


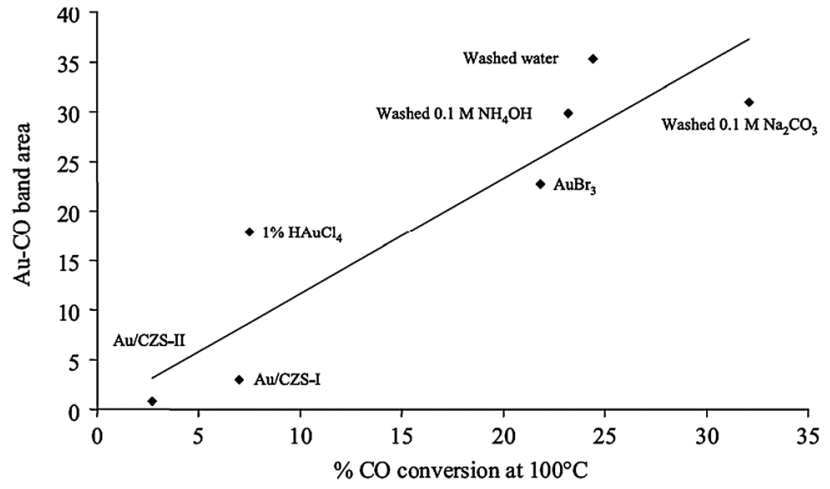

Fig. 2 The correlation between CO conversions on several catalysts at $100{ }^{\circ} \mathrm{C}$ under WGS conditions and $\mathrm{Au}-\mathrm{CO}$ band areas for room temperature adsorption of $\mathrm{CO}$ on these catalysts. Catalysts include: (a) $2 \% \mathrm{Au} / \mathrm{CeZrO}_{4}$ (prepared from $\mathrm{HAuCl}_{4}$ ) washed with water, $0.1 \mathrm{M} \mathrm{NH}_{4} \mathrm{OH}$ or $0.1 \mathrm{M} \mathrm{Na}_{2} \mathrm{CO}_{3} ;$ (b) $2 \% \mathrm{Au} / \mathrm{CeZrO}_{4}$ prepared from $\mathrm{AuBr}_{3}$ washed with water; (c) $1 \% \mathrm{Au} / \mathrm{CeZrO}_{4}$ prepared from $\mathrm{HAuCl}_{4}$ washed with water; and (d) sulfated $\mathrm{Au} / \mathrm{CeZrO}_{4}$ catalysts (Au/CZS-I and Au/CZS-II). ${ }^{70}$ Reproduced with permission of Elsevier from R. Pilasombat, H. Daly, A. Goguet, J. P. Breen, R. Burch, C. Hardacre and D. Thompsett, Catal. Today, 2012, 180, 131.

probe for infrared characterization and the $\mathrm{Au}-\mathrm{CO}$ band area correlated to the number of surface gold sites.

To develop new gold catalysts for WGSR, one idea is to use metal oxide supports with morphologies or structures different from conventional ones. For instance, mesoporous $\mathrm{TiO}_{2},{ }^{71,72} \mathrm{TiO}_{2}$ nanotubes, ${ }^{73}$ mesoporous $\mathrm{ZrO}_{2},{ }^{74}$ mesoporous $\mathrm{CeO}_{2},{ }^{72,75,76}$ and $\mathrm{CeO}_{2}$ nanorods ${ }^{75,77,78}$ were used as supports to load gold. Although these gold catalysts all showed some activities in WGSR, the focus in these publications was mainly on the synthesis and characterization of catalytic materials.

Interestingly, Andreeva and co-workers showed that crystalline $\mathrm{ZrO}_{2}$ and $\mathrm{TiO}_{2}$ were better than amorphous ones in making active gold catalysts for WGSR. ${ }^{47,48}$ Shen and co-workers studied the influence of the crystal phase of the $\mathrm{ZrO}_{2}$ support on catalytic activity. ${ }^{79}$ The tetragonal $\mathrm{ZrO}_{2}\left(13 \mathrm{~nm}, 96 \mathrm{~m}^{2} \mathrm{~g}^{-1}\right)$ was prepared by homogeneous precipitation and calcined at $450{ }^{\circ} \mathrm{C}$, whereas the monoclinic $\mathrm{ZrO}_{2}\left(5 \mathrm{~nm}, 136 \mathrm{~m}^{2} \mathrm{~g}^{-1}\right)$ was prepared using a reflex method and calcined at $450{ }^{\circ} \mathrm{C}$. The $\mathrm{Au} /$ monoclinic $\mathrm{ZrO}_{2}$ showed higher activity than $\mathrm{Au} /$ tetragonal $\mathrm{ZrO}_{2}$ in WGSR. To rule out the surface area effect, another monoclinic $\mathrm{ZrO}_{2}$ support $\left(91 \mathrm{~m}^{2} \mathrm{~g}^{-1}\right)$ was prepared by calcination at $500{ }^{\circ} \mathrm{C}$. The trend in activity order was the same. The authors demonstrated, by CO-TPD measurements, that $\mathrm{Au} /$ monoclinic $\mathrm{ZrO}_{2}$ adsorbed more $\mathrm{CO}$ than $\mathrm{Au} /$ tetragonal $\mathrm{ZrO}_{2}$, therefore explaining the activity difference. ${ }^{79}$

Shen and co-workers further investigated the influence of particle sizes on the performance of $\mathrm{Au} / \mathrm{ZrO}_{2} \cdot{ }^{80}$ The size of the monoclinic $\mathrm{ZrO}_{2}$ support was adjusted by changing the calcination temperature $\left(450-850{ }^{\circ} \mathrm{C}\right)$ of $\mathrm{ZrO}_{2}$, whereas the size of gold nanoparticles was varied by changing the calcination temperature $\left(250-550{ }^{\circ} \mathrm{C}\right)$ of $\mathrm{Au} / \mathrm{ZrO}_{2}$ prepared by loading gold onto $\mathrm{ZrO}_{2}$ calcined at $550{ }^{\circ} \mathrm{C}$. The $\mathrm{CO}$ conversion decreased greatly when the size of the $\mathrm{ZrO}_{2}$ support increased from 7 to $55 \mathrm{~nm}$ (at a fixed gold particle size of $3 \mathrm{~nm}$ ). On the other hand, the $\mathrm{CO}$ conversion decreased greatly when the size of gold nanoparticles increased from 2.9 to $6.2 \mathrm{~nm}$ (at a fixed $\mathrm{ZrO}_{2}$ particle size of $30 \mathrm{~nm}$ ).

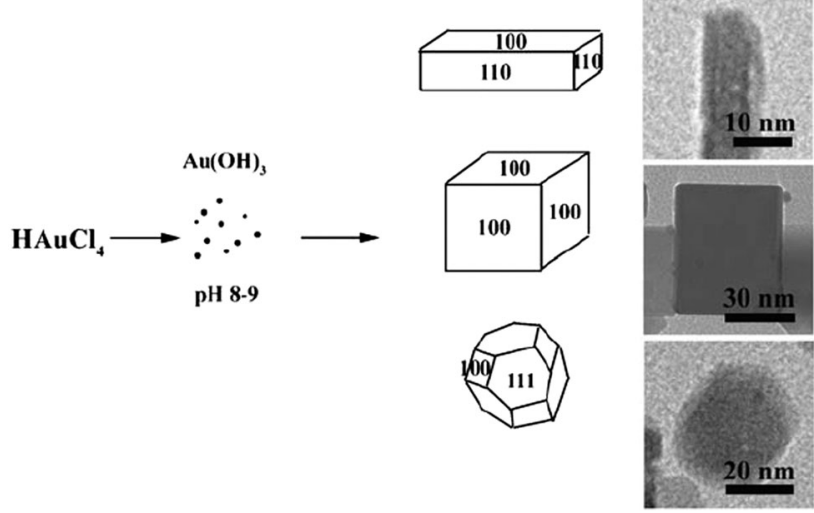

Fig. 3 Scheme showing the two-step synthesis of $\mathrm{Au}$ on $\mathrm{CeO}_{2}$ nanorods, nanocubes, and nanopolyhedra. ${ }^{77}$ First, $\mathrm{CeO}_{2}$ supports with different morphologies were prepared using a controlled hydrothermal technique. Second, gold was loaded onto these supports by deposition-precipitation using $\mathrm{HAuCl}_{4}$ as a precursor. Reproduced with permission of Wiley-VCH from R. Si and M. Flytzani-Stephanopoulos, Angew. Chem., Int. Ed., 2008, 47, 2884

These results, coupled with IR data, showed the importance of the $\mathrm{Au}-\mathrm{ZrO}_{2}$ interface for WGSR. Apparently, there will be more $\mathrm{Au}-\mathrm{ZrO}_{2}$ contact boundaries if the sizes of gold nanoparticles and the $\mathrm{ZrO}_{2}$ support are decreased.

Flytzani-Stephanopoulos and co-workers performed very interesting studies on the influence of crystal planes of $\mathrm{CeO}_{2}$ on the supported gold catalysts. ${ }^{77} \mathrm{CeO}_{2}$ nanorods (with $\{110\}$ and $\{100\}$ planes), nanocubes (with $\{100\}$ planes), and polyhedra (with $\{111\}$ and $\{100\}$ planes) were prepared via a hydrothermal method, and gold was loaded onto the supports via depositionprecipitation (Fig. 3). ${ }^{70}$ The activities in WGSR followed the sequence of $\mathrm{Au} / \mathrm{CeO}_{2}$ nanorods $>\mathrm{Au} / \mathrm{CeO}_{2}$ polyhedra $\gg \mathrm{Au} /$ $\mathrm{CeO}_{2}$ nanocubes, probably because of the presence of a much higher fraction of strongly bound gold species on the former two catalysts, as confirmed by others. ${ }^{81}$ In addition, a theoretical study indicated that oxygen vacancies are easier to form on $\mathrm{CeO}_{2}\{110\}$ than $\{100\}$ and $\{111\}$ planes, ${ }^{82}$ thus explaining the stabilization of gold species on $\mathrm{CeO}_{2}$ nanorods. A similar effect was established for the methanol steam reforming on $\mathrm{Au} / \mathrm{CeO}_{2}$ catalysts ${ }^{83}$ and the shape effects on metal oxide supported gold catalysts in WGSR were reported in $\mathrm{Au} / \mathrm{ZnO}$ and $\mathrm{Au} / \mathrm{Fe}_{3} \mathrm{O}_{4}$ systems. ${ }^{84}$

Another approach of catalyst development is to adjust the chemical composition of the supported metal. Scurrell and co-workers demonstrated the better performance of $\mathrm{Au}-\mathrm{Ru} /$ $\mathrm{Fe}_{2} \mathrm{O}_{3}$ than $\mathrm{Ru} / \mathrm{Fe}_{2} \mathrm{O}_{3}$ and $\mathrm{Au} / \mathrm{Fe}_{2} \mathrm{O}_{3}$ in WGSR. ${ }^{85}$ The authors extended this idea to the preparation of Au-based "bimetallic" catalysts $\mathrm{Au}-\mathrm{M} / \mathrm{Fe}_{2} \mathrm{O}_{3},{ }^{86}$ where $\mathrm{M}$ stands for $\mathrm{Ag}, \mathrm{Bi}, \mathrm{Co}, \mathrm{Cu}, \mathrm{Mn}, \mathrm{Ni}$, $\mathrm{Pb}, \mathrm{Ru}, \mathrm{Sn}$, or $\mathrm{Tl}$. These catalysts were prepared using the deposition-coprecipitation method using $\mathrm{HAuCl}_{4}, \mathrm{Fe}\left(\mathrm{NO}_{3}\right)_{3}$, and metal salts (mostly metal nitrates), and were calcined in air at $400{ }^{\circ} \mathrm{C}$. It is not clear whether these additives are all metallic before or during WGSR, considering that the thermal decomposition of soluble metal nitrates usually leads to the formation of metal oxides. ${ }^{87}$ Although some metal oxide additives may be reduced during WGSR, the local structures of the $\mathrm{Au}$ and $\mathrm{M}$ components and their interactions are not clear. 
In situ studies using ambient pressure electron spectroscopy and environment electron microscopy may elucidate the chemical state of $\mathrm{M}$ and its interaction with Au during catalysis. Other supported bimetallic catalysts tested in WGSR include $\mathrm{Au}-\mathrm{Pt} / \mathrm{CeO}_{2},{ }^{88,89} \mathrm{Au}-\mathrm{Pd} / \mathrm{CeO}_{2},{ }^{88} \mathrm{Au}-\mathrm{Re} / \mathrm{CeO}_{2},{ }^{90}$ and $\mathrm{Au}-\mathrm{Pt} / \mathrm{FSM}-16 .{ }^{91}$ A synergistic effect was often claimed, but the nature of promotion is not clear.

A third approach of catalyst development is to change the composition of the support, either by preparing mixed oxide supports or by loading another metal oxide onto a neat support. Reported catalysts in the first category include $\mathrm{Au} / \mathrm{Fe}_{2} \mathrm{O}_{3}-\mathrm{ZnO},{ }^{47}$ $\mathrm{Au} / \mathrm{Fe}_{2} \mathrm{O}_{3}-\mathrm{ZrO}_{2},{ }^{47,92,93} \mathrm{Au} / \mathrm{FeO}_{x}-\mathrm{CrO}_{x},{ }^{94} \mathrm{Au} / \mathrm{CeO}_{2}-\mathrm{Al}_{2} \mathrm{O}_{3},{ }^{95-98} \mathrm{Au} /$ $\mathrm{CeO}_{2}-\mathrm{Ga}_{2} \mathrm{O}_{3},{ }^{99} \mathrm{Au} / \mathrm{CeO}_{2}-\mathrm{Fe}_{2} \mathrm{O}_{3},{ }^{100,101} \mathrm{Au} / \mathrm{CeO}_{2}-\mathrm{SnO}_{2},{ }^{101} \mathrm{Au} / \mathrm{CeO}_{2}-$ $\mathrm{MnO}_{2},{ }^{101} \mathrm{Au} / \mathrm{Cu}_{x} \mathrm{Mn}_{y} \mathrm{O}_{z},{ }^{102} \mathrm{Au} / \mathrm{CeO}_{2}-\mathrm{TiO}_{2},{ }^{103} \mathrm{Au} / \mathrm{CeO}_{2}-\mathrm{Y}_{2} \mathrm{O}_{3},{ }^{104}$ $\mathrm{Au} / \mathrm{CeO}_{2}-\mathrm{Sm}_{2} \mathrm{O}_{3},{ }^{98,104} \mathrm{Au} / \mathrm{CeO}_{2}-\mathrm{Gd}_{2} \mathrm{O}_{3},{ }^{104} \mathrm{Au} / \mathrm{CeO}_{2}-\mathrm{Yb}_{2} \mathrm{O}_{3},{ }^{104}$ $\mathrm{Au} / \mathrm{CeO}_{2}-\mathrm{La}_{2} \mathrm{O}_{3},{ }^{104-107}$ and $\mathrm{Au} / \mathrm{CeO}_{2}-\mathrm{ZrO}_{2} \cdot{ }^{70,97,108-110}$ Although some metal oxide dopants did not show any positive effect, ${ }^{92}$ others were found to be beneficial. For instance, the addition of $\mathrm{ZrO}_{2}$ to $\mathrm{Fe}_{2} \mathrm{O}_{3}$ was shown to stabilize gold nanoparticles and retard the reduction of $\mathrm{Fe}_{2} \mathrm{O}_{3} \cdot{ }^{92}$

Examples in the second category include $\mathrm{Au} / \mathrm{CeO}_{2} /$ mesoporous $\quad \mathrm{TiO}_{2},{ }^{111,112} \mathrm{Au} / \mathrm{CeO}_{2} /$ mesoporous $\mathrm{ZrO}_{2},{ }^{113}$ $\mathrm{Au} / \mathrm{M}_{x} \mathrm{O}_{y} / \mathrm{TiO}_{2},{ }^{61,114} \mathrm{Au} / \mathrm{SO}_{4}{ }^{2-} / \mathrm{ZrO}_{2},{ }^{115,116} \mathrm{Au} / \mathrm{Co}_{3} \mathrm{O}_{4} / \mathrm{CeO}_{2},{ }^{117}$ $\mathrm{Au} / \mathrm{CuO} / \mathrm{CeO}_{2},{ }^{118,119}$ and $\mathrm{Au} / \mathrm{TiO}_{x} / \mathrm{C}^{53-55}$ For example, Ma et al. found that some $\mathrm{Au} / \mathrm{M}_{x} \mathrm{O}_{y} / \mathrm{TiO}_{2}$ catalysts showed higher activities than $\mathrm{Au} / \mathrm{TiO}_{2}$ in $\mathrm{CO}$ oxidation and WGSR when these catalysts were calcined at elevated temperatures. ${ }^{61,87}$ Fig. 4 shows the specific rates of $\mathrm{Au} / \mathrm{M}_{x} \mathrm{O}_{y} / \mathrm{TiO}_{2}$ catalysts in WGSR at $300{ }^{\circ} \mathrm{C}$, highlighting the promotional effect of $\mathrm{Al}_{2} \mathrm{O}_{3}, \mathrm{CaO}, \mathrm{Y}_{2} \mathrm{O}_{3}$, $\mathrm{ZrO}_{2}$, and rare earth metal oxides. ${ }^{61}$ These metal oxide additives may stabilize gold nanoparticles against thermal sintering during calcination. Of course, the adjustment of the redox properties of supports and creation of surface defects/oxygen vacancies cannot be excluded. The latter aspect should be studied in more detail in the future.

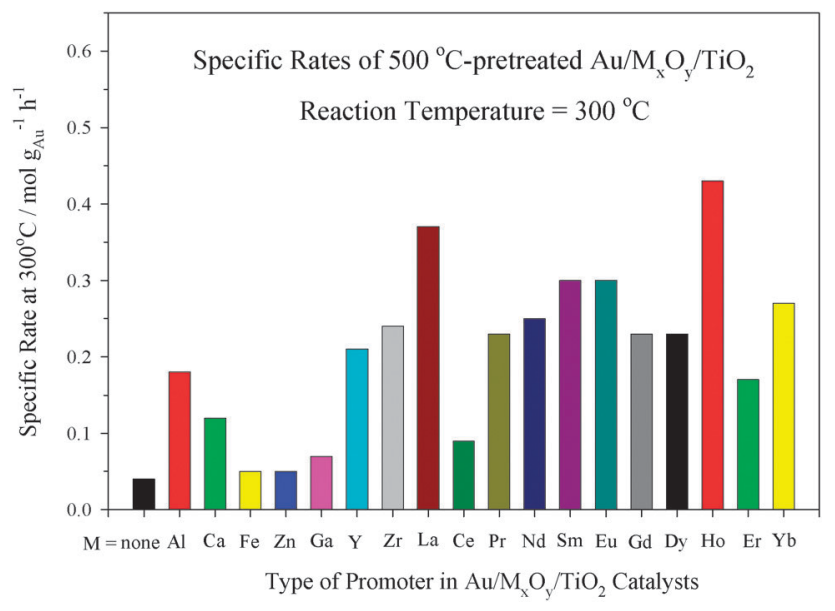

Fig. 4 Effect of $\mathrm{M}_{x} \mathrm{O}_{y}$ modifiers on the catalytic performance (in terms of specific rates at a reaction temperature of $300{ }^{\circ} \mathrm{C}$ ) of $\mathrm{Au} / \mathrm{M}_{x} \mathrm{O}_{y} / \mathrm{TiO}_{2}$ catalysts in WGSR. ${ }^{61}$ These catalysts were pretreated at $500{ }^{\circ} \mathrm{C}$ prior to reaction testing. Reproduced with permission of Springer from Z. Ma, H. F. Yin and S. Dai, Catal. Lett., 2010, 136, 83

\section{Catalyst stability and deactivation}

Catalyst stability is very important for practical operation. The antonym of catalyst stability is catalyst deactivation. Catalyst deactivation generally has many reasons, such as sintering of supported metals, crystallization and structural collapse of porous supports, poisoning by strong adsorbates such as sulfur and heavy metals, and accumulation of reaction intermediates. In the initial publications on WGSR over supported gold catalysts, the focus was more on catalytic activity than on stability. ${ }^{41-44}$ In recent years, more and more attention has been paid to the stability of gold catalysts in WGSR and their deactivation mechanisms.

Osuwan and co-workers compared the catalytic performance of $\mathrm{Pt} / \mathrm{CeO}_{2}, \mathrm{Au} / \mathrm{CeO}_{2}$, and $\mathrm{Au} / \mathrm{Fe}_{2} \mathrm{O}_{3}$ in WGSR. ${ }^{120}$ While $\mathrm{Pt} / \mathrm{CeO}_{2}$ was relatively stable on stream, the $\mathrm{CO}$ conversion on $\mathrm{Au} / \mathrm{CeO}_{2}$ decreased from $60 \%$ to about $10 \%$ within $48 \mathrm{~h}$ at $360{ }^{\circ} \mathrm{C}$. The authors ascribed the catalyst deactivation to the agglomeration of gold nanoparticles from 4 to $5.5 \mathrm{~nm}$. Although the growth of gold nanoparticles may be the case, the deactivation of gold catalysts should not be solely ascribed to sintering. In addition, care should be taken when using uncalcined catalysts directly in high-temperature reactions without any pretreatment. Under such conditions, the growth of metal nanoparticles during the reaction is more likely.

Thompson and co-workers concluded, based on XPS and infrared data, that the catalyst deactivation on $\mathrm{Au} / \mathrm{CeO}_{2}$ was caused primarily by blockage of the active sites by carbonates and/or formates. ${ }^{121}$ The formation of these reaction intermediates was promoted by oxygen deficient sites, and a used catalyst can be recovered by calcining in air to decompose these reaction intermediates. Fig. 5 highlights infrared evidence for the presence of surface intermediates during reaction and the removal of surface intermediates by thermal treatment in air. ${ }^{121}$ In this figure, infrared peaks near 1300, 1500, 2800, and $2900 \mathrm{~cm}^{-1}$ are ascribed to formate species, and those at 1300 and $1400 \mathrm{~cm}^{-1}$ are characteristic of carbonates. The regeneration of catalysts by thermal treatment under oxidation ambient was observed with other catalysts including $\mathrm{Au} /$ mesoporous $\mathrm{ZrO}_{2}{ }^{74}$ and the deactivation mechanism was demonstrated experimentally using $\mathrm{Au} / \mathrm{CeO}_{2} \cdot{ }^{122,123}$ The deactivation of course depends on reaction conditions, for instance becomes more obvious in the presence of $\mathrm{CO}_{2}$ due to the enhanced formation of carbonates on catalyst surfaces. ${ }^{122}$

Makkee and co-workers investigated the deactivation mechanism of $\mathrm{Au} / \mathrm{Fe}_{2} \mathrm{O}_{3}$ in WGSR. ${ }^{124}$ Although carbonate and carbonyl species were formed during the reaction, they were not regarded as the main cause of deactivation. Instead, the support changed from $\mathrm{Fe}_{2} \mathrm{O}_{3}$ to $\mathrm{Fe}_{3} \mathrm{O}_{4}$ during WGSR, resulting in a significant loss of surface area. The fast deactivation of $\mathrm{Au} / \mathrm{Co}_{3} \mathrm{O}_{4}$ catalysts during WGSR was also explained by the reduction of the support. ${ }^{48}$ The presence of gold on catalyst supports may promote the reduction of supports, as explained by the activation of $\mathrm{H}_{2}$ on gold and the spillover of the atomic hydrogen to the support. ${ }^{48,125}$

Hardacre and co-workers, with the aid of EXAFS, XANES, and DFT calculations, proposed another mechanism for the deactivation of $\mathrm{Au} / \mathrm{CeZrO}_{4} \cdot{ }^{126}$ The deactivation was ascribed to 


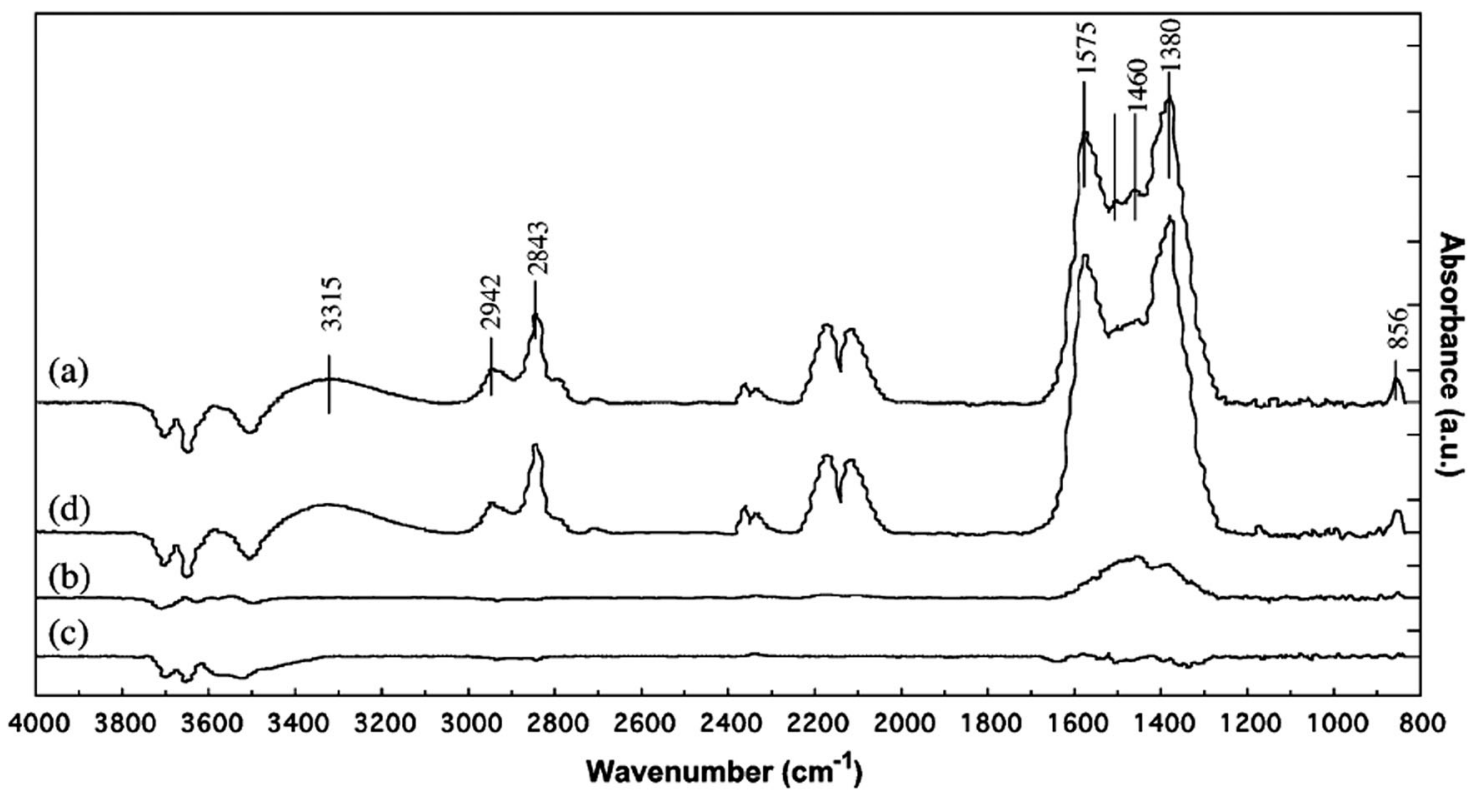

Fig. 5 Infrared spectra of the $\mathrm{Au} / \mathrm{CeO}_{2}$ catalyst following treatment in (a) the $\mathrm{CO}+\mathrm{H}_{2}$ mixture for $4 \mathrm{~h}$ at $240{ }^{\circ} \mathrm{C}$; (b) air for $1 \mathrm{~h}$ at $240{ }^{\circ} \mathrm{C}$; (c) air for 30 min at $400{ }^{\circ} \mathrm{C}$; and (d) re-exposure to the $\mathrm{CO}+\mathrm{H}_{2}$ mixture for $1 \mathrm{~h}$ at $240{ }^{\circ} \mathrm{C} .{ }^{121}$ Reproduced with permission of Elsevier from C. H. Kim and L. T. Thompson, J. Catal., $2005,230,66$.

the concentration of water that may dewet the gold atoms from the support, i.e., the gold on the support progressively detached, therefore weakening the metal-support interaction. They later provided a further explanation for the deactivation of $\mathrm{Au} / \mathrm{CeZrO}_{4}$, considering that the rate of change in the $\mathrm{Au}^{0}-\mathrm{CO}$ infrared bands correlated with the deactivation rate under all conditions whereas the $\mathrm{Au}^{\delta+}-\mathrm{CO}$ species disappeared more rapidly on stream. ${ }^{127}$

It should be cautioned that the deactivation of gold catalysts in WGSR depends critically on the nature of catalysts and reaction conditions such as reaction temperatures and gas compositions. $^{128}$ The oxidative regeneration of gold catalysts at elevated temperatures may not only be related to the removal of intermediates or strong adsorbates, but also be likely due to the re-dispersion of gold nanoparticles in the support and the recovery of the surface oxygen amount, as is the case with the $\mathrm{Au} / \mathrm{Ce}(\mathrm{La}) \mathrm{O}_{x}$. atalyst. $^{129}$

\section{Nature of active sites}

Understanding the nature of active sites is important for studying reaction mechanisms. However, due to different preparation methods and testing conditions, and also due to varied investigation approaches and the extent or depth of research approaches, the nature of active sites is still being debated in the literature. For instance, in the initial studies, Mohamed and co-workers loaded $\mathrm{AuCl}_{3}$ on zeolites without further reduction, and found IR evidence for the dominance of $\mathrm{Au}^{+}$in WGSR at $50{ }^{\circ} \mathrm{C} .{ }^{130}$ They therefore proposed that cation gold is responsible for WGSR. Other researchers, based on FTIR experiments, proposed that metallic gold nanoparticles in close contact with $\mathrm{Fe}_{2} \mathrm{O}_{3}, \mathrm{TiO}_{2}$, or $\mathrm{CeO}_{2}$ supports are responsible for high activity in WGSR. ${ }^{131,132}$

Flytzani-Stephanopoulos and co-workers obtained a very interesting finding that cationic gold is responsible for WGSR. ${ }^{15}$
An aqueous $\mathrm{NaCN}$ was used to selectively leach metallic gold from $\mathrm{Au} / \mathrm{La}-\mathrm{CeO}_{2}$ and $\mathrm{Au} / \mathrm{Fe}_{2} \mathrm{O}_{3}$, leaving behind cationic gold species in close contact with the supports. ${ }^{133}$ The leached and unleached catalysts showed the same activities in WGSR (Fig. 6), ${ }^{133}$ whereas the leached catalysts were less active than their unleached counterparts in CO oxidation, implying different site requirements for these two reactions: cationic gold is responsible for WGSR, whereas metallic gold is responsible for CO oxidation. This finding is very interesting, because oxidizing gold usually represents a small proportion of gold species on the catalyst surface whereas they were shown to have high activities in WGSR. The authors later studied the oxidation states of gold in $\mathrm{Au} / \mathrm{Ce}(\mathrm{La}) \mathrm{O}_{x}$ and concluded that cationic gold species can be reduced under WGS conditions, but the extent of reduction depends on reaction temperature and gas composition. ${ }^{129}$ In addition, a UV-irradiation technique was used to prepare $\mathrm{Au} /$ $\mathrm{TiO}_{2}$ catalysts with Au- $(\mathrm{OH})_{x}$ surface species active for WGSR. ${ }^{134}$ Mildly oxidized gold atoms anchored on $\mathrm{TiO}_{2}$ were proposed as active sites in this study. ${ }^{134}$ DFT calculations suggested that it is possible for cationic gold in the vicinity of oxygen vacancies to catalyze WGSR. ${ }^{136}$ In addition, it was claimed that isolated surface $\mathrm{Au}^{3+}$ ions are active sites for selective hydrogenation of 1,3-butadiene on $\mathrm{Au} / \mathrm{ZrO}_{2} \cdot{ }^{137}$ Hensen and co-workers showed that the cationic gold in leached $\mathrm{Au} / \mathrm{CeO}_{2}$ could be partially reduced to metallic gold clusters active for hydrogenation of 1,3-butadiene, CO oxidation, and WGSR. ${ }^{81,138}$

Rodriguez and co-workers studied $\mathrm{Au} / \mathrm{Ce}(\mathrm{Gd}) \mathrm{O}_{2}$ and $\mathrm{Au} /$ $\mathrm{CeO}_{x} / \mathrm{TiO}_{2}$ using in situ time-resolved X-ray absorption spectroscopy (TR-XAS). ${ }^{114,140}$ They also found the transformation of cationic gold into metallic gold under WGS conditions. The importance of metallic gold in WGSR catalyzed by $\mathrm{Au} / \mathrm{Al}_{2} \mathrm{O}_{3},{ }^{141}$ $\mathrm{Au} / \mathrm{TiO}_{2}{ }^{142} \mathrm{Au} / \mathrm{CeO}_{2}{ }^{66,76,135}$ and $\mathrm{Au} / \mathrm{CeZrO}_{4}{ }^{139}$ was suggested. In particular, Ribeiro and co-workers provided detailed evidence 


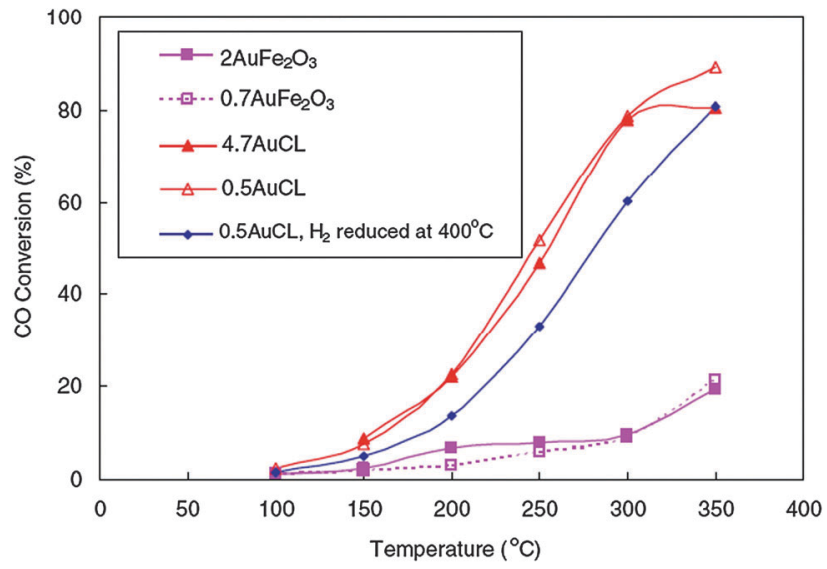

Fig. 6 WGS reaction light-off curves over $\mathrm{Au} / \mathrm{Ce}(\mathrm{La}) \mathrm{O}_{x}$ (denoted as $\mathrm{AuCL}$ ) and $\mathrm{Au} / \mathrm{Fe}_{2} \mathrm{O}_{3}$ (denoted as $\mathrm{AuFe}_{2} \mathrm{O}_{3}$ ) catalysts before and after $\mathrm{NaCN}$ leaching. ${ }^{133}$ The $\mathrm{NaCN}$ leaching decreases the gold loading, leaving behind some cationic gold on support surfaces. Reproduced with permission of Springer from W. L. Deng, C. Carpenter, N. Yi and M. Flytzani-Stephanopoulos, Top. Catal., 2007, 44, 199.

for the importance of metallic corner atoms in gold clusters supported on $\mathrm{TiO}_{2}{ }^{52,142,143}$

Based on these in situ and ex situ studies, probably both metallic and cationic gold species exist during WGS catalysis. This is understandable, because the reduction degree of gold depends on various factors such as the nature of supports, the preparation method, and the operation conditions. A real challenge is to distinguish the role of metallic and the cationic gold species since (1) both types of gold species likely coexist during WGSR and (2) the fraction of cationic gold existing at the interface of gold and oxide in a working Au/oxide catalyst is small. This technical challenge in distinguishing the cationic gold, a small fraction of all Au species during WGSR, from metallic Au atoms prevents us from conclusively identifying the role of cationic and metallic Au. In addition, the nature of active sites is critically dependent on the nature of supports and even operation conditions; the observation of one type of active site in one study does not necessarily exclude the presence of another type of active site in another study (using another catalyst or under another operation condition). Thus, more studies are certainly necessary before catalytic active sites of WGSR on Au/oxide catalysts could be elucidated.

\section{Reaction mechanisms}

WGSR, no matter carried out using gold catalysts or other catalysts, is generally considered to proceed via two mechanisms, a regenerative, redox mechanism and an associate mechanism. ${ }^{144,145}$ In the redox mechanism, CO reacts with a reducible oxide support to form $\mathrm{CO}_{2}$, leading to the partial reduction of the support. Water then oxidizes the partially reduced support by furnishing oxygen, releasing $\mathrm{H}_{2}$. Normally the support is a reducible metal oxide, and the reaction takes place at high temperatures. Fig. 7 shows a scheme for the process. ${ }^{48}$ The associative mechanism involves the formation of surface intermediates $\mathrm{CH}_{x} \mathrm{O}_{y}$ (e.g., carbonates and formates)

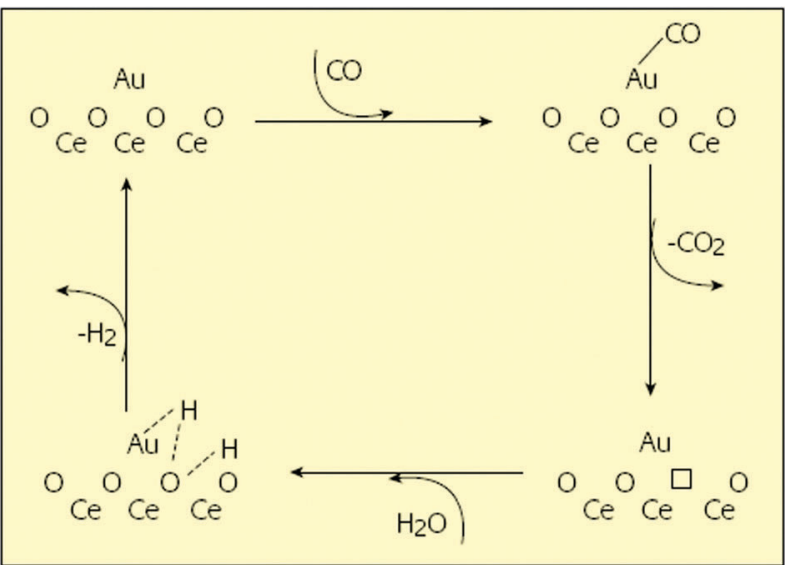

Fig. 7 A mechanism proposed for WGSR, involving the participation of the support. ${ }^{48}$ In this case, $\mathrm{CeO}_{2}$ support is used as a representative. Reproduced with permission of Springer from D. Andreeva, Gold Bull., 2002, 35, 82.

and the decomposition of these intermediates to $\mathrm{CO}_{2}$ and $\mathrm{H}_{2}$. It is possible for the reduction and reoxidation of the support in the associative mechanism. For instance, Andreeva and co-workers initially proposed an associative mechanism in which water dissociates on gold nanoparticles, followed by the spillover of active hydroxyl groups onto adjacent sites of the $\mathrm{Fe}_{2} \mathrm{O}_{3}$ support. $^{42}$ The formation and decomposition of intermediates are accompanied by the redox transfer $\mathrm{Fe}^{3+} \rightarrow \mathrm{Fe}^{2+}$ in $\mathrm{Fe}_{3} \mathrm{O}_{4}$ and the reoxidation of $\mathrm{Fe}^{2+}$ during the dissociation of water.

Sakurai and co-workers, based on transient experiments consisting of injecting $\mathrm{CO}$ and $\mathrm{H}_{2} \mathrm{O}$ pulses into $\mathrm{H}_{2}$ and $\mathrm{He}$ streams, proposed that WGSR on $\mathrm{Au} / \mathrm{CeO}_{2}$ proceeds at the perimeter interfaces of small gold nanoparticles and a reduced $\mathrm{CeO}_{x}$ surface, via the formation of a reaction intermediate (e.g., formate) from $\mathrm{CO}$ and $\mathrm{OH}$ groups, followed by decomposition of the intermediate. ${ }^{146}$ A similar associative mechanism involving the decomposition of intermediates was proposed for WGSR on $\mathrm{Au} / \mathrm{CeO}_{2}{ }^{147-150}$ and $\mathrm{Au} / \mathrm{ZrO}_{2}{ }^{79}$ based on the detection of such intermediates by FT-IR.

Meunier and co-workers investigated the reactivity of the $\mathrm{Au} / \mathrm{Ce}(\mathrm{La}) \mathrm{O}_{2}$ catalyst in WGSR using operando diffuse reflectance Fourier transform spectroscopy (DRIFTS). ${ }^{151}$ The authors found that the rate of formate decomposition on catalyst surfaces was 60 -fold smaller than the rate of $\mathrm{CO}_{2}$ formation (Fig. 8), indicating the minority role of formates in the reaction mechanism. The same approach was used to study WGSR on $\mathrm{Au} / \mathrm{CeZrO}_{4}$, and a similar conclusion was made. ${ }^{152}$ Although the authors ruled out the significant contribution of the formate channel, they did not suggest what the actual mechanism is in operation. On the other hand, Makkee and co-workers conducted a study using mass spectrometry (MS) coupled with DRIFTS, and concluded that the redox mechanism was valid for WGSR on $\mathrm{Au} / \mathrm{Fe}_{2} \mathrm{O}_{3}$ although the formate channel was also observed. ${ }^{153}$

It should be mentioned that the reaction mechanisms in operation depend critically on the nature of catalysts, preparation methods and details, pretreatment conditions, reaction temperatures, and reaction gas compositions. Therefore, it is not surprising that different mechanisms have been proposed. 


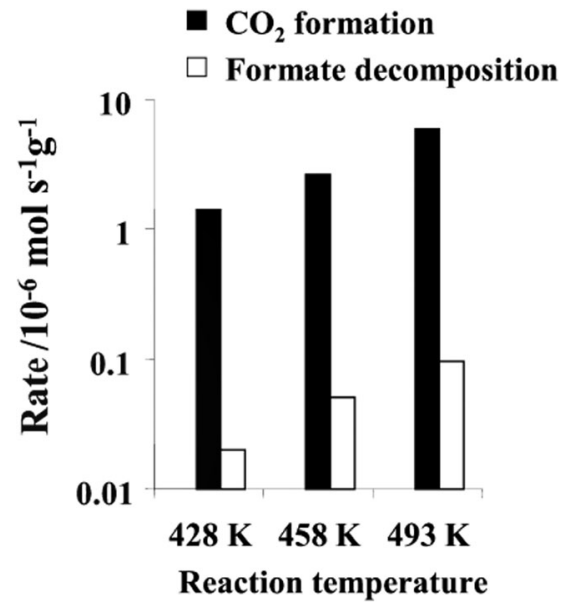

Fig. 8 Rate of $\mathrm{CO}_{2}$ production and the rate of formate decomposition over the $\mathrm{Au} / \mathrm{Ce}(\mathrm{La}) \mathrm{O}_{2}$ catalyst at three different temperatures under $2 \% \mathrm{CO}+7 \% \mathrm{H}_{2} \mathrm{O} .{ }^{151}$ Reproduced with permission of Elsevier from F. C. Meunier, D. Reid, A. Goguet, S. Shekhtman, C. Hardacre, R. Burch, W. Deng and M. Flytzani-Stephanopoulos, J. Catal., 2007, 247, 277.

The WGS reaction mechanisms on gold catalysts have been discussed in an excellent review by Burch. ${ }^{144}$ There, the author proposed a "universal" model to account for many experimental observations, and the dominant surface intermediates still depend on reaction conditions.

\section{Surface science studies}

Surface science studies are critical for understanding the fundamental aspects of catalysis. First, one may construct model catalyst systems and vary the composition, structure, size, and the oxidation state of the components in a controlled manner. Second, the welldefined model catalysts can be characterized by surface-sensitive instruments under various pretreatment and reaction conditions, thus helping with the identification of reaction intermediates and the correlation of kinetics data with active sites. ${ }^{154-156}$

Rodriguez and co-workers performed pioneering surface science studies on low-temperature WGS catalysts. They nicely studied gold nanoclusters/nanoparticles supported on a well-defined $\mathrm{CeO}_{2}(111)$ or rough $\mathrm{CeO}_{2}$ films as model catalysts. ${ }^{140}$ The activity of reduced $\mathrm{AuO}_{x} / \mathrm{CeO}_{2}$ (actually $\mathrm{Au} / \mathrm{CeO}_{1.88}$ ) was higher than that of reduced $\mathrm{Au} / \mathrm{CeO}_{2}(111)$ (actually $\mathrm{Au} / \mathrm{CeO}_{1.94}(111)$ ), because the former catalyst contained more surface defects and oxygen vacancies (Fig. 9). ${ }^{\mathbf{1 4 0}}$ Besides, the activity of $\mathrm{Au} / \mathrm{CeO}_{2}(111)$ depended on the gold coverage, being the highest when the coverage was 0.4-0.5 ML. This study indicated that the active phase may involve small gold clusters $(<2 \mathrm{~nm})$ and oxygen vacancies. ${ }^{140}$ The presence of gold nanoparticles may facilitate the partial reduction of $\mathrm{CeO}_{2}$ by $\mathrm{CO}$ or the $\mathrm{CO}+\mathrm{H}_{2} \mathrm{O}$ mixture, and the created oxygen vacancies may dissociate $\mathrm{H}_{2} \mathrm{O} .{ }^{157}$ The authors first designed $\mathrm{Au} / \mathrm{CeO}_{x} / \mathrm{TiO}_{2}(110)$ reverse catalysts with even higher activities in WGSR due to the special chemical properties of the supported $\mathrm{Ce}_{2} \mathrm{O}_{3}$ dimers and cooperative effects at $\mathrm{Au}-\mathrm{CeO}_{x}$ interfaces. ${ }^{158,159}$

The importance of metal-support interfacial sites was nicely shown in a surface science study using model catalysts, i.e.,
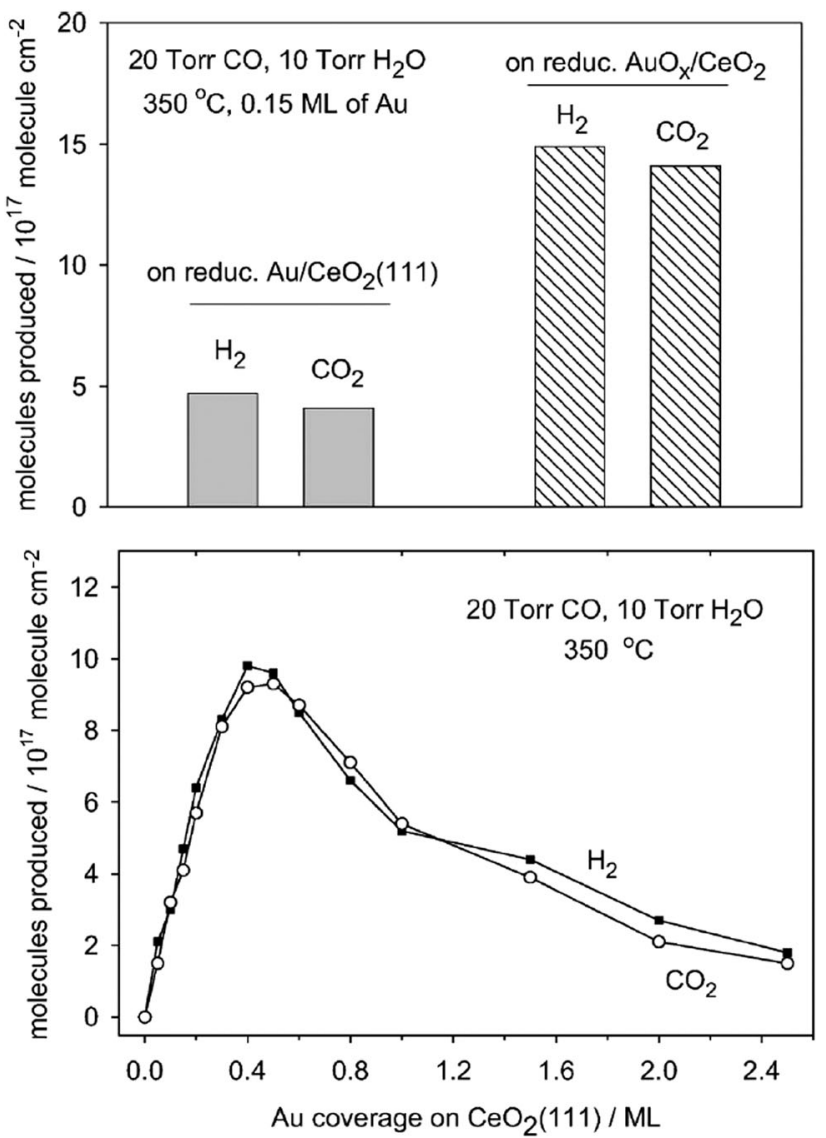

Fig. 9 Top panel: amounts of $\mathrm{H}_{2}$ and $\mathrm{CO}_{2}$ produced during WGSR on reduced $\mathrm{Au} / \mathrm{CeO}_{2}(111)$ and $\mathrm{AuO}_{x} / \mathrm{CeO}_{2}\left(\theta_{\mathrm{Au}} \sim 0.15 \mathrm{ML}\right)$ catalysts. Bottom panel: amounts of $\mathrm{H}_{2}$ and $\mathrm{CO}_{2}$ produced during the WGS reaction on reduced $\mathrm{Au} / \mathrm{CeO}_{2}(111)$ catalysts with different Au coverages. ${ }^{140}$ Reproduced with permission of American Institute of Physics from X. Wang, J. A. Rodriguez, J. C. Hanson, M. Pérez and J. Evans, J. Chem. Phys., 2005, 123, 221101.

$\mathrm{CeO}_{x}$ and $\mathrm{TiO}_{x}$ nanoclusters grown on the $\mathrm{Au}(111)$ substrate. ${ }^{160}$ It was found that the WGS activities peaked when the surface coverages of $\mathrm{CeO}_{x}$ or $\mathrm{TiO}_{x}$ were optimal (20-30\%), and the $\mathrm{CeO}_{x}$ or $\mathrm{TiO}_{2}$ had plenty of oxygen vacancies for dissociating water. The $\mathrm{Au}(111)$ substrate remained metallic after WGSR, and some formate and carbonate species were detected, implying the potential role of the associative mechanism. ${ }^{160,161}$ Although the reported "inverse" catalysts are not the same as regular supported catalysts such as $\mathrm{Au} / \mathrm{CeO}_{2}$ and $\mathrm{Au} / \mathrm{TiO}_{2}$, this work did provide fundamental implications for the nature of active sites and reaction mechanisms in the WGSR system. It should be mentioned that Vannice and co-workers previously deposited $\mathrm{TiO}_{x}$ overlayers onto an inactive gold powder, and demonstrated the high activity of this "inverse" catalyst in CO oxidation, ${ }^{162}$ therefore highlighting the importance of $\mathrm{Au}-\mathrm{TiO}_{x}$ interfacial sites in CO oxidation.

\section{Concluding remarks}

Here we summarized recent progress in the development of gold catalysts for WGSR and briefly reviewed efforts in fundamental 
studies toward elucidating the catalytic mechanism on Au/oxide catalysts. It is known that $\mathrm{Fe}_{2} \mathrm{O}_{3}, \mathrm{TiO}_{2}, \mathrm{ZrO}_{2}, \mathrm{CeO}_{2}$ and their modified versions are often suitable for loading gold catalysts for WGSR, whereas non-reducible $\mathrm{SiO}_{2}$ and $\mathrm{Al}_{2} \mathrm{O}_{3}$ are not suitable. Attempts have been made to improve the synthesis procedures of catalysts or to develop new WGS catalysts with more complex compositions/structures.

From the examples highlighted above, we may conclude that the deactivation mechanisms, nature of active sites, and reaction mechanisms are still being debated. Different mechanisms were proposed. For Au/oxide WGS catalysts, it is quite challenging to apply the insights obtained from one system to rationalize the catalytic performance of another catalyst since different experimental conditions (e.g., different catalysts, preparation details, and reaction conditions) could have been applied in studies of different catalysts. For example, the gas compositions in different studies were dramatically different, therefore influencing the oxidation state and deactivation of gold catalysts subtly.

In the studies of deactivation mechanisms, nature of active sites, and reaction mechanisms, interesting phenomena (i.e., certain change in particle size, change in structure, or the presence of certain species in the deactivation study, the detection of certain gold species) were reported. Such phenomena may or may not be directly relevant to catalytic performance; sometimes a phenomenon can solely be regarded as a side effect, and a species can be regarded as a spectator that is not related to catalysis. In addition, as is well known that surface structure at the level of a single crystallite could be quite dynamic, local surface chemistry and structure during catalysis could be different from those characterized before and/or after catalysis. From this point of view, it is necessary to explore surface chemistry and structure of Au/oxide WGS catalysts during catalysis by using different in situ techniques to study the nature of active sites, deactivation mechanisms, and reaction mechanisms, and correlation of physicochemical changes with kinetics data is necessary to make a strong case.

Most of the research efforts we reviewed here adopted idealized reaction conditions since they are fundamental studies of catalysis science. For industrial applications, it is important to study WGS catalysis and catalysts under industrial operation conditions such as using a mixture of gas of industrial production in the process of shut-down/start-up. ${ }^{163,164}$ For instance, commercial industrial WGS catalysts are usually sensitive to the exposure to air and moisture and are sensitive to sulfur-containing substances in the reaction mixture. How Au/oxide catalysts in WGS could change under a realistic industrial condition is important for potential applications of $\mathrm{Au} /$ oxide catalysts in chemical industries. There are several reports on the performance of $\mathrm{Au} / \mathrm{SO}_{4}{ }^{2-} / \mathrm{ZrO}_{2},{ }^{115,116} \mathrm{Au} / \mathrm{SO}_{4}{ }^{2-}$ / $\mathrm{CeZrO}_{4},{ }^{70}$ and $\mathrm{Au} / \mathrm{La}_{2} \mathrm{O}_{2} \mathrm{SO}_{4}{ }^{165}$ catalysts in WGSR, as well as the surface chemistry of $\mathrm{SO}_{2}$ on $\mathrm{Au} / \mathrm{CeO}_{2}$ model catalysts, ${ }^{166}$ but the influence of $\mathrm{SO}_{2}$ or $\mathrm{H}_{2} \mathrm{~S}$ impurity on the performance of gold catalysts in WGSR was virtually not reported. The future progress is expected to not only lead to the development of practical catalysts for fuel cell applications, but also help understand more on the molecular aspects of catalysis.

\section{Acknowledgements}

Z. Ma thanks the financial support by National Natural Science Foundation of China (Grant Nos. 21007011 and 21177028), the PhD programs foundation of the Ministry of Education in China (Grant No. 20100071120012), and the overseas returnees start-up research fund of the Ministry of Education in China. This work was partially supported by NSF-MRI under grant no.1126374 and NSFC under grant no. 21228301.

\section{References}

1 D. E. Ridler and M. V. Twigg, in Catalyst Handbook, ed. M. V. Twigg, Wolfe Publishing, London, 2nd edn, 1989, p. 225.

2 Y. H. Hu and E. Ruckenstein, Catal. Rev.: Sci. Eng., 2002, 44, 423.

3 Y. H. Hu and E. Ruckenstein, Adv. Catal., 2004, 48, 297.

4 L. Lloyd, D. E. Ridler and M. V. Twigg, in Catalyst Handbook, ed. M. V. Twigg, Wolfe Publishing, London, 2nd edn, 1989, p. 283.

5 D. S. Newsome, Catal. Rev., 1980, 21, 275.

6 C. Rhodes, G. J. Hutchings and A. M. Ward, Catal. Today, 1995, 23, 43.

7 D. Cameron, R. Holliday and D. Thompson, J. Power Sources, 2003, 118, 298.

8 D. L. Trimm, Appl. Catal., A, 2005, 296, 1.

9 M. Haruta, T. Kobayashi, H. Sano and N. Yamada, Chem. Lett., 1987, 405.

10 M. Haruta, N. Yamada, T. Kobayashi and S. Iijima, J. Catal., 1989, 115, 301.

11 M. Valden, X. Lai and D. W. Goodman, Science, 1998, 281, 1647.

12 G. C. Bond and D. T. Thompson, Catal. Rev.: Sci. Eng., 1999, 41, 319.

13 M. Haruta and M. Daté, Appl. Catal., A, 2001, 222, 427.

14 T. V. Choudhary and D. W. Goodman, Top. Catal., 2002, 21, 25.

15 Q. Fu, H. Saltsburg and M. Flytzani-Stephanopoulos, Science, 2003, 301, 935.

16 H. H. Kung and M. C. Kung, Appl. Catal., A, 2003, 246, 193.

17 A. S. K. Hashmi and G. J. Hutchings, Angew. Chem., Int. Ed., 2006, 45, 7896.

18 G. C. Bond, C. Louis and D. T. Thompson, Catalysis by Gold, Imperial College Press, London, 2006.

19 S. A. C. Carabineiro and D. T. Thompson, in Nanocatalysis, ed. U. Heiz and U. Landman, Springer, Berlin, 2007, p. 377.

20 M. C. Kung, R. J. Davis and H. H. Kung, J. Phys. Chem. C, 2007, 111, 11767.

21 T. V. W. Janssens, B. S. Clausen, B. Hvolbæk, H. Falsig, C. H. Christensen, T. Bligaard and J. K. Nørskov, Top. Catal., 2007, 44, 15.

22 B. K. Min and C. M. Friend, Chem. Rev., 2007, 107, 2709.

23 G. J. Hutchings, Chem. Commun., 2008, 10, 1148.

24 M. S. Chen and D. W. Goodman, Chem. Soc. Rev., 2008, 37, 1860 . 
25 C. Della Pina, E. Falletta, L. Prati and M. Rossi, Chem. Soc. Rev., 2008, 37, 2077.

26 A. Corma and H. Garcia, Chem. Soc. Rev., 2008, 37, 2096.

27 J. C. Fierro-Gonzalez and B. C. Gates, Chem. Soc. Rev., 2008, 37, 2127.

28 Z. Ma and S. Dai, Nano Res., 2011, 4, 3.

29 Z. Ma and S. Dai, ACS Catal., 2011, 1, 805.

30 M. Haruta, Faraday Discuss., 2011, 152, 11.

31 L. Parti and A. Villa, Catalysts, 2012, 2, 24.

32 C. Della Pina, E. Falletta and M. Rossi, Chem. Soc. Rev., 2012, 41, 350 .

33 Y. Zhang, X. J. Cui, F. Shi and Y. Q. Deng, Chem. Rev., 2012, 112, 2467.

34 J. L. Gong, Chem. Rev., 2012, 112, 2987.

35 M. Stratakis and H. Garcia, Chem. Rev., 2012, 112, 4469.

36 T. Takei, K. Akita, I. Nakamura, T. Fujitani, M. Okumura, K. Okazaki, J. H. Huang, T. Ishida and M. Haruta, Adv. Catal., 2012, 55, 1.

37 T. Mallat and A. Baiker, Annu. Rev. Chem. Biomol. Eng., 2012, 3, 11.

38 M. Flytzani-Stephanopoulos and B. C. Gates, Annu. Rev. Chem. Biomol. Eng., 2012, 3, 545.

39 T. Barakat, J. C. Rooke, E. Genty, R. Cousin, S. Siffert and B.-L. Su, Energy Environ. Sci., 2013, 6, 371.

40 S. E. Davis, M. S. Ide and R. J. Davis, Green Chem., 2013, 15, 17. 41 D. Andreeva, V. Idakiev, T. Tabakova and A. Andreev, J. Catal., 1996, 158, 354.

42 D. Andreeva, V. Idakiev, T. Tabakova, A. Andreev and R. Giovanoli, Appl. Catal., A, 1996, 134, 275.

43 D. Andreeva, T. Tabakova, V. Idakiev, P. Christov and R. Giovanoli, Appl. Catal., A, 1998, 169, 9.

44 H. Sakurai, A. Ueda, T. Kobayashi and M. Haruta, Chem. Commun., 1997, 271.

45 Q. Fu, A. Weber and M. Flytzani-Stephanopoulos, Catal. Lett., 2001, 77, 87.

46 D. Andreeva, V. Idakiev, T. Tabakova, L. Ilieva, P. Falaras, A. Bourlinos and A. Travlos, Catal. Today, 2002, 72, 51.

47 T. Tabakova, V. Idakiev, D. Andreeva and I. Mitov, Appl. Catal., A, 2000, 202, 91.

48 D. Andreeva, Gold Bull., 2002, 35, 82.

49 T. Tabakova, V. Idakiev, K. Tenchev, F. Boccuzzi, M. Manzoli and A. Chiorino, Appl. Catal., B, 2006, 63, 94.

50 S. Kudo, T. Maki, T. Fukuda and K. Mae, Catalysts, 2011, 1, 175 .

51 A. Sandoval, A. Gomez-Cortes, R. Zanella, G. Diaz and J. M. Saniger, J. Mol. Catal. A: Chem., 2007, 278, 200.

52 M. Shekhar, J. Wang, W.-S. Lee, W. D. Williams, S. M. Kim, E. A. Stach, J. T. Miller, W. N. Delgass and F. H. Ribeiro, J. Am. Chem. Soc., 2012, 134, 4700.

53 N. Hammer, I. Kvande, D. Chen and M. Rønning, Catal. Today, 2007, 122, 365.

54 N. Hammer, I. Kvande, X. Xu, V. Gunnarsson, B. Tøtdal, D. Chen and M. Rønning, Catal. Today, 2007, 123, 245.

55 S. Gil, A. Romero, A. de Lucas, P. Sánchez, F. Dorado, A. R. de la Osa, J. M. García-Vargas and J. L. Valverde, Catalysts, 2011, 1, 155.
56 A. Venugopal and M. S. Scurrell, Appl. Catal., A, 2003, 245, 137.

57 W. F. Yan, S. Brown, Z. W. Pan, S. M. Mahurin, S. H. Overbury and S. Dai, Angew. Chem., Int. Ed., 2006, 45, 3614.

58 Z. Ma, H. F. Yin, S. H. Overbury and S. Dai, Catal. Lett., 2008, 126, 20.

59 M. J. Li, Z. L. Wu, Z. Ma, V. Schwartz, D. R. Mullins, S. Dai and S. H. Overbury, J. Catal., 2009, 266, 98.

60 Z. Ma, H. F. Yin and S. Dai, Catal. Lett., 2010, 138, 40.

61 Z. Ma, H. F. Yin and S. Dai, Catal. Lett., 2010, 136, 83.

62 Q. Fu, S. Kudriavtseva, H. Saltsburg and M. FlytzaniStephanopoulos, Chem. Eng. J., 2003, 93, 41.

63 T. Tabakova, F. Boccuzzi, M. Manzoli, J. W. Sobczak, V. Idakiev and D. Andreeva, Appl. Catal., B, 2004, 49, 73.

64 J. M. Hua, K. M. Wei, Q. Zheng and X. Y. Lin, Appl. Catal., A, 2004, 259, 121.

65 G. Jacobs, S. Ricote, P. M. Patterson, U. M. Graham, A. Dozier, S. Khalid, E. Rhodus and B. H. Davis, Appl. Catal., A, 2005, 292, 229.

66 A. Karpenko, R. Leppelt, V. Plzak, J. Cai, A. Chuvilin, B. Schumacher, U. Kaiser and R. J. Behm, Top. Catal., 2007, 44, 183.

67 B. A. Lenite, C. Galletti and S. Specchia, Int. J. Hydrogen Energy, 2011, 36, 7750.

68 Y. J. Zhang, Y. Y. Zhan, Y. N. Cao, C. Q. Chen, X. Y. Liu and Q. Zheng, Chin. J. Catal., 2012, 33, 230.

69 Y. J. Zhang, Y. Y. Zhan, C. Q. Chen, Y. N. Cao, X. Y. Liu and Q. Zheng, Int. J. Hydrogen Energy, 2012, 37, 12292.

70 R. Pilasombat, H. Daly, A. Goguet, J. P. Breen, R. Burch, C. Hardacre and D. Thompsett, Catal. Today, 2012, 180, 131.

71 V. Idakiev, T. Tabakova, Z.-Y. Yuan and B.-L. Su, Appl. Catal., A, 2004, 270, 135.

72 D. H. Wang, Z. Ma, S. Dai, J. Liu, Z. M. Nie, M. H. Engelhard, Q. S. Huo, C. M. Wang and R. Kou, J. Phys. Chem. C, 2008, 112, 13499.

73 V. Idakiev, Z. Y. Yuan, T. Tabakova and B. L. Su, Appl. Catal., A, 2005, 281, 149.

74 V. Idakiev, T. Tabakova, A. Naydenov, Z. Y. Yuan and B. L. Su, Appl. Catal., B, 2006, 63, 178.

75 Z.-Y. Yuan, V. Idakiev, A. Vantomme, T. Tabakova, T.-Z. Ren and B.-L. Su, Catal. Today, 2008, 131, 203.

76 C. Wen, Y. Zhu, Y. C. Ye, S. R. Zhang, F. Cheng, Y. Liu, P. Wang and F. Tao, ACS Nano, 2012, 6, 9305.

77 R. Si and M. Flytzani-Stephanopoulos, Angew. Chem., Int. Ed., 2008, 47, 2884.

78 N. Ta, J. Y. Liu, S. Chenna, P. A. Crozier, A. L. Chen and W. J. Shen, J. Am. Chem. Soc., 2012, 134, 20585.

79 J. Li, J. L. Chen, W. Song, J. L. Liu and W. J. Shen, Appl. Catal., A, 2008, 334, 321.

80 J. Li, N. Ta, W. Song, E. S. Zhan and W. J. Shen, Gold Bull., 2009, 42, 48.

81 Y. J. Guan, D. A. J. M. Ligthart, Ö. Pirgon-Galin, J. A. Z. Pieterse, R. A. van Santen and E. J. M. Hensen, Top. Catal., 2011, 54, 424. 
82 T. X. T. Sayle, S. C. Parker and D. C. Sayle, Phys. Chem. Chem. Phys., 2005, 7, 2936.

83 N. Yi, R. Si, H. Saltburg and M. Flytzani-Stephanopoulos, Energy Environ. Sci., 2010, 3, 831.

84 M. B. Boucher, S. Goergen, N. Yi and M. FlytzaniStephanopoulos, Phys. Chem. Chem. Phys., 2011, 13, 2517.

85 A. Venugopal, J. Aluha, D. Mogano and M. S. Scurrell, Appl. Catal., A, 2003, 245, 149.

86 A. Venugopal, J. Aluha and M. S. Scurrell, Catal. Lett., 2003, 90, 1.

87 Z. Ma, S. H. Overbury and S. Dai, J. Mol. Catal. A: Chem., 2007, 273, 186.

88 M.-A. Hurtado-Juan, C. M. Y. Yeung and S. C. Tsang, Catal. Commun., 2008, 9, 1551.

89 Q. Q. Yu, W. Chen, Y. Li, M. S. Jin and Z. H. Suo, Catal. Today, 2010, 158, 324.

90 B. S. Çağlayan and A. E. Aksoylu, Catal. Commun., 2011, 12, 1206.

91 M. M. Mohamed and M. Ichikawa, J. Colloid Interface Sci., 2011, 354, 100.

92 J. M. Hua, Q. Zheng, Y. H. Zheng, K. M. Wei and X. Y. Lin, Catal. Lett., 2005, 102, 99.

93 J. S. K. Teo, S. P. Teh, W. P. Addiego, Z. Y. Zhong, A. Borgna and R. E. Truitt, Int. J. Hydrogen Energy, 2011, 36, 5763.

94 G. N. Vajani, S. L. Ng and C. R. F. Lund, Ind. Eng. Chem. Res., 2011, 50, 10493.

95 D. Andreeva, I. Ivanova, L. Ilieva and M. V. Abrashev, Appl. Catal., A, 2006, 302, 127.

96 D. Andreeva, I. Ivanov, L. Ilieva, J. W. Sobczak, G. Avdeev and K. Petrov, Top. Catal., 2007, 44, 173.

97 C. Galletti, S. Specchia, G. Saracco and V. Specchia, Top. Catal., 2009, 52, 688.

98 D. Andreeva, M. Kantcheva, I. Ivanov, L. Ilieva, J. Sobczak and W. Lisowski, Catal. Today, 2010, 158, 69.

99 J. Vecchietti, S. Collins, J. J. Delgado, M. Małecka, E. del Rio, X. W. Chen, S. Bernal and A. Bonivardi, Top. Catal., 2011, 54, 201.

100 T. Tabakova, M. Manzoli, D. Paneva, F. Boccuzzi, V. Idakiev and I. Mitov, Appl. Catal., B, 2011, 101, 266.

101 T. Tabakova, L. Ilieva, I. Ivanov, R. Zanella, J. W. Sobczak, W. Lisowski, Z. Kaszkur and D. Andreeva, Appl. Catal., B, 2013, 136-137, 70.

102 Y. S. She, W. H. Sun, Y. Y. Zhan, X. Y. Lin and Q. Zheng, Chin. J. Catal., 2011, 32, 1220.

103 M. Manzoli, F. Vindigni, A. Chiorino, T. Tabakova, V. Idakiev and F. Boccuzzi, React. Kinet. Catal. Lett., 2007, 91, 213.

104 D. Andreeva, I. Ivanov, L. Ilieva, M. V. Abrashev, R. Zanella, J. W. Sobczak, W. Lisowski, M. Kantcheva, G. Avdeev and K. Petrov, Appl. Catal., A, 2009, 357, 159.

105 Q. Zhang, Y. Y. Zhan, X. Y. Lin and Q. Zheng, Catal. Lett, 2007, 115, 143.

106 Y. N. Wang, S. Liang, A. M. Cao, R. L. Thompson and G. Veser, Appl. Catal., B, 2010, 99, 89.

107 S. Liang and G. Veser, Catal. Lett., 2012, 142, 936.

108 A. A. Fonseca, J. M. Fisher, D. Ozkaya, M. D. Shannon and A. Thompsett, Top. Catal., 2007, 44, 223.
109 M. Boaro, M. Vicario, J. Llorca, C. de Leitenburg, G. Dolcetti and A. Trovarelli, Appl. Catal., B, 2009, 88, 272.

110 F. Vindigni, M. Manzoli, T. Tabakova, V. Idakiev, F. Boccuzzi and A. Chiorino, Appl. Catal., B, 2012, 125, 507.

111 V. Idakiev, T. Tabakova, K. Tenchev, Z.-Y. Yuan, T.-Z. Ren and B.-L. Su, Catal. Today, 2007, 128, 223.

112 V. Idakiev, T. Tabakova, K. Tenchev, Z. Y. Yuan, Z. T. Ren, A. Vantomme and B. L. Su, J. Mater. Sci., 2009, 44, 6637.

113 V. Idakiev, T. Tabakova, K. Tenchev, Z.-Y. Yuan, T.-Z. Ren and B.-L. Su, J. Porous Mater., 2012, 19, 15.

114 R. Si, J. Tao, J. Evans, J. B. Park, L. Barrio, J. C. Hanson, Y. M. Zhu, J. Hrbek and J. A. Rodriguez, J. Phys. Chem. C, 2012, 116, 23547.

115 F. Menegazzo, F. Pinna, M. Signoretto, V. Trevisan, F. Boccuzzi, A. Chiorino and M. Manzoli, ChemSusChem, 2008, 1, 320.

116 F. Zane, V. Trevisan, F. Pinna, M. Signoretto and F. Menegazzo, Appl. Catal., B, 2009, 89, 303.

117 N. K. Gamboa-Rosales, J. L. Ayastuy, A. Iglesias-González, M. P. González-Marcos and M. A. Gutiérrez-Ortiz, Chem. Eng. J., 2012, 207-208, 49.

118 N. K. Gamboa-Rosales, J. L. Ayastuy, M. P. GonzálezMarcos and M. A. Gutiérrez-Ortiz, Catal. Today, 2011, 176, 63.

119 N. K. Gamboa-Rosales, J. L. Ayastuy, M. P. GonzálezMarcos and M. A. Gutiérrez-Ortiz, Int. J. Hydrogen Energy, 2012, 37, 7005.

120 A. Luengnaruemitchai, S. Osuwan and E. Gulari, Catal. Commun., 2003, 4, 215.

121 C. H. Kim and L. T. Thompson, J. Catal., 2005, 230, 66.

122 Y. Denkwitz, A. Karpenko, V. Plzak, R. Leppelt, B. Schumacher and R. J. Behm, J. Catal., 2007, 246, 74.

123 A. Karpenko, R. Leppelt, J. Cai, V. Plzak, A. Chuvilin, U. Kaiser and R. J. Behm, J. Catal., 2007, 250, 140.

124 B. A. A. Silberova, S. M. Makkee and J. A. Moulijin, Top. Catal., 2007, 44, 209.

125 L. Ilieva, D. Andreeva and A. Andreev, Thermochim. Acta, 1997, 292, 169.

126 A. Goguet, R. Burch, Y. Chen, C. Hardacre, P. Hu, R. W. Joyner, F. C. Meunier, B. S. Mun, D. Thompsett and D. Tibiletti, J. Phys. Chem. C, 2007, 111, 16927.

127 H. Daly, A. Goguet, C. Hardacre, F. C. Meunier, R. Pilasombat and D. Thompsett, J. Catal., 2010, 273, 257.

128 A. A. El-Moemen, G. Kćerová and R. J. Behm, Appl. Catal., $B, 2010,95,57$.

129 W. L. Deng, A. I. Frenkel, R. Si and M. Flytzani-Stephanopoulos, J. Phys. Chem. C, 2008, 112, 12834.

130 M. M. Mohamed and M. Ichikawa, J. Colloid Interface Sci., 2000, 232, 381.

131 F. Boccuzzi, A. Chiorino, M. Manzoli, D. Andreeva and T. Tabakova, J. Catal., 1999, 188, 176.

132 T. Tabakova, F. B. Boccuzzi, M. Manzoli and D. Andreeva, Appl. Catal., A, 2003, 252, 385.

133 W. L. Deng, C. Carpenter, N. Yi and M. FlytzaniStephanopoulos, Top. Catal., 2007, 44, 199.

134 M. Yang, L. F. Allard and M. Flytzani-Stephanopoulos, J. Am. Chem. Soc., 2013, 135, 3768. 
135 C. H. Kim and L. T. Thompson, J. Catal., 2006, 244, 248.

136 Z. P. Liu, S. J. Jenkins and D. A. King, Phys. Rev. Lett., 2005, 94, 196102.

137 X. Zhang, H. Shi and B.-Q. Xu, Angew. Chem., Int. Ed., 2005, 44, 7132.

138 Y. Guan and E. J. M. Hensen, Phys. Chem. Chem. Phys., 2009, 11, 9578.

139 D. Tibiletti, A. Amieiro-Fonseca, R. Burch, Y. Chen, J. M. Fisher, A. Goguet, C. Hardacre, P. Hu and A. Thompsett, J. Phys. Chem. B, 2005, 109, 22553.

140 X. Wang, J. A. Rodriguez, J. C. Hanson, M. Perez and J. Evans, J. Chem. Phys., 2005, 123, 221101.

141 N. Guo, B. R. Fingland, W. D. Williams, V. F. Kispersky, J. Jelic, W. N. Delgass, F. H. Ribeiro, R. J. Meyer and J. T. Miller, Phys. Chem. Chem. Phys., 2010, 12, 5678.

142 W. D. Williams, M. Shekhar, W.-S. Lee, V. Kispersky, W. N. Delgass, F. H. Ribeiro, S. M. Kim, E. A. Stach, J. Miller and L. F. Allard, J. Am. Chem. Soc., 2010, 132, 14018.

143 M. Shekhar, J. Wang, W.-S. Lee, M. C. Akatay, E. A. Stach, W. N. Delgass and F. H. Ribeiro, J. Catal., 2012, 293, 94.

144 R. Burch, Phys. Chem. Chem. Phys., 2006, 8, 5483.

145 G. C. Bond, Gold Bull., 2009, 42, 337.

146 H. Sakurai, T. Akita, S. Tsubota, M. Kiuchi and M. Haruta, Appl. Catal., A, 2005, 291, 179.

147 G. Jacobs, E. Chenu, P. M. Patterson, L. Williams, D. Sparks, G. Thomas and B. H. Davis, Appl. Catal., A, 2004, 258, 203.

148 G. Jacobs, P. M. Patterson, L. Williams, E. Chenu, D. Sparks, G. Thomas and B. H. Davis, Appl. Catal., A, 2004, 262, 177.

149 T. Tabakova, F. Boccuzzi, M. Manzoli, J. W. Sobczak, V. Idakiev and D. Andreeva, Appl. Catal., A, 2006, 298, 127.

150 R. Leppelt, B. Schumacher, V. Plzak, M. Kinne and R. J. Behm, J. Catal., 2006, 244, 137.
151 F. C. Meunier, D. Reid, A. Goguet, S. Shekhtman, C. Hardacre, R. Burch, W. Deng and M. Flytzani-Stephanopoulos, J. Catal., 2007, 247, 277.

152 F. C. Meunier, A. Goguet, C. Hardacre, R. Burch and D. Thompsett, J. Catal., 2007, 252, 18.

153 B. A. A. Silberova, G. Mul, M. Makkee and J. A. Moulijn, J. Catal., 2006, 243, 171.

154 X. Q. Wang, J. A. Rodriguez, J. C. Hanson, D. Gamarra, A. Martínez-Arias and M. Fernández-García, Top. Catal, 2008, 49, 81.

155 J. Rodriguez, Catal. Today, 2011, 160, 3.

156 Y. C. Ye, S. R. Zhang, Y. Zhu, J. J. Shan and F. Tao, Chem. Commun., 2013, 49, 4385.

157 J. A. Rodriguez, P. Liu, J. Hrbek, J. Evans and M. Pérez, Angew. Chem., Int. Ed., 2007, 46, 1329.

158 J. B. Park, J. Graciani, J. Evans, D. Stacchiola, S. G. Ma, P. Liu, A. Nambu, J. F. Sanz, J. Hrbek and J. A. Rodrigues, Proc. Natl. Acad. Sci. U. S. A., 2009, 106, 4975.

159 J. Graciani, J. J. Plata, J. F. Sanz, P. Liu and J. A. Rodriguez, J. Chem. Phys., 2010, 132, 104703.

160 J. A. Rodriguez, S. Ma, P. Liu, J. Hrbek, J. Evans and M. Perez, Science, 2007, 318, 1757.

161 S. Senanayake, D. Stacchiola, J. Evans, M. Estrella, L. Barrio, M. Pérez, J. Hrbek and J. A. Rodriguez, J. Catal., 2010, 271, 392.

162 M. A. Bollinger and M. A. Vannice, Appl. Catal., B, 1996, 8, 417. 163 Q. Fu, W. L. Deng, H. Saltsburg and M. FlytzaniStephanopoulos, Appl. Catal., B, 2005, 56, 57.

164 W. L. Deng and M. Flytzani-Stephanopoulos, Angew. Chem., Int. Ed., 2006, 45, 2285.

165 J. D. Lessard, I. Valsamakis and M. Flytzani-Stephanopoulos, Chem. Commun., 2012, 48, 4857.

166 J. A. Rodriguez, X. Wang, P. Liu, W. Wen, J. C. Hanson, J. Hrbek, M. Perez and J. Evans, Top. Catal., 2007, 44, 73. 